Acta vet. scand. $1974,15,442-444$.

Brief Communication

\title{
THE ABSORPTION OF SULPHADIMIDINE IN COD FISH
}

Drug therapy in fish poses certain problems because of the special anatomical and physiological considerations involved, as well as the large numbers which usually have to be treated at the same time. In fish farming (aquaculture) etc. it has been the common practice, when required, to add drugs to the feed. In some cases injections have also been used. Both these methods of administering drugs have their disadvantages, however, and studies concerning alternative means of drug administration are therefore of interest. In this paper, a pilot study where the drug was added to the water, in which the fish were kept, is described.

It is considered that absorption from water can take place in part via the gills. Considerable absorption will also probably occur through the gut, as salt water fish swallow water in order to maintain their internal environment (Motais \& Garcia-Romell 1972).

Certain species of fish are able to live for shorter periods of time under conditions of greatly varying $\mathrm{pH}$ (Reite et al. 1974). In the light of this fact, and of the observations made by Rasmussen (1966) on the distribution of drugs between milk and blood plasma, two media with different $\mathrm{pH}$, it seems natural to see if $\mathrm{pH}$ changes in the external environment can be made use of in the drug therapy in fish.

The fish used in the trial were codfish weighing from 800 to $1200 \mathrm{~g}$. They were dividod into groups of three, each group being placed in a separate vessel containing $120 \mathrm{l}$ of water which was oxygenated using an aquarium pump. The water was not cleaned. Sulphadimidine (sodium salt) was added to the water such that the final concentration in the water was $1000 \mathrm{mg}$ sulphadimidine/l. The $\mathrm{pH}$ of the water was adjusted to 6.0 and 10.0, respectively, in the two series making up the trial. Analyses were carried out after $6,12,24,48$ and 96 hrs. The fish did not seem to show any signs of functional disturbances during the trial periods of up to four days. After the pre-determined period of time, the fish were stunned by a blow on the head, and blood samples were taken from the ventral aorta. Samples of tissue were taken from the liver, musculature and kidneys. After weigh- 
ing, these samples were homogenized together with a double amount of distilled water, and analysed with regard to their sulphonamide content using the King et al. modification (1942) of the method of Bratton \& Marshall (1939). The blood samples were analysed directly using the same method.

Sulphadimidine is an acid with a pKa $=7.4$. According to Shore et al. (1957), the following formula can be used to calculate distribution in compantments with differing $\mathrm{pH}$ which are separated by biological membranes:

$$
\frac{\mathrm{C}_{1}}{\mathrm{C}_{2}}=\frac{1+10^{\mathrm{pH}_{1}-\mathrm{pKa}}}{1+10^{\mathrm{pH}_{2}-\mathrm{pKa}}}
$$

where $C_{1}$ and $C_{2}$ are the total concentrations of the drug in the two media.

If the passage of the drug from the water to the blood of the fish takes place according to the same law, and provided that

$\mu g$ sulphadimidine/g tissue

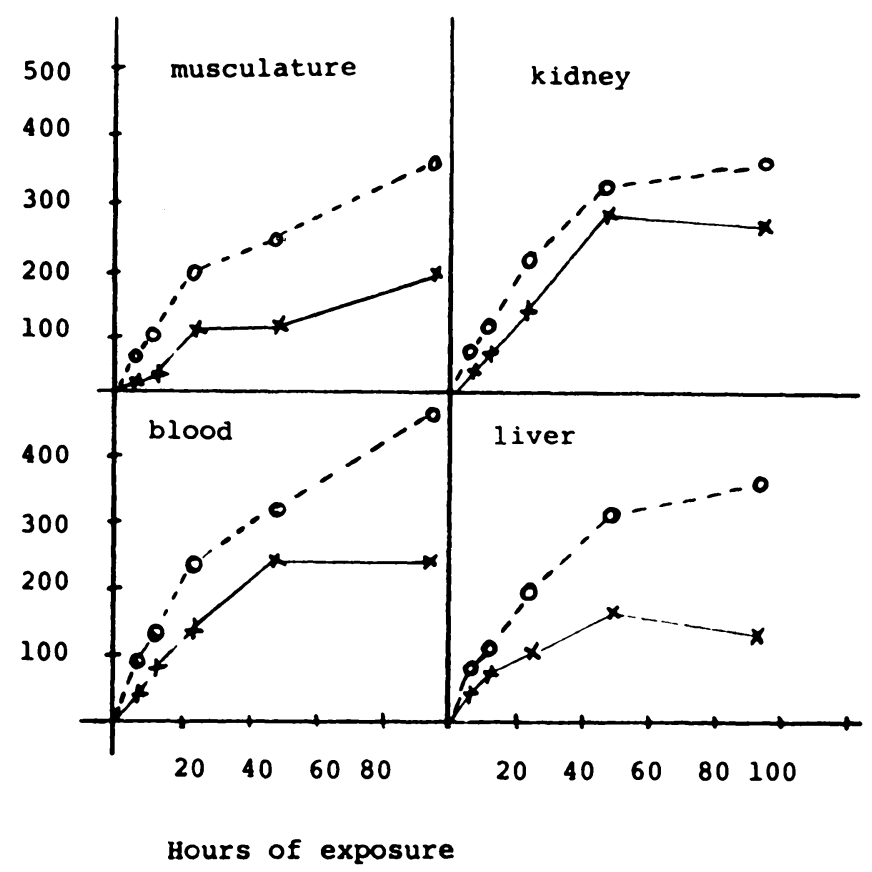

Blood and tissue concentrations of sulphadimidine as a function of the time for which the fish was immersed in the water containing $1000 \mathrm{mg}$ sulphadimidine/l at varying $\mathrm{pH}$.

$\mathrm{pH}=6.0: 0 \cdot \cdots \cdot-\mathrm{o}^{2}$

$\mathrm{pH}=10.0: \times \longrightarrow$ 
the $\mathrm{pH}$ of the fish bloods is 7.4 , one would expect a higher concentration of sulphonamide in the tissue of the fish with a water $\mathrm{pH}$ of 6.0 than with a water $\mathrm{pH}$ of 10.0.

Results are shown in the figure.

In this study, no effort was made to determine the degree to which protein binding of the sulphonamide in the tissue of the fish had taken place. Nevertheless, the tendency is clear: absorption of the drug from the water by the fish seems to depend on the $\mathrm{pH}$ of the water in which the fish is immersed.

Although it did not prove possible to demonstrate acetylated sulphadimidine, results from a less comprehensive study seem to indicate that acetylation of other sulphonamides can occur. Acetylation of sulphanilamide has been demonstrated by Smith (1968).

The fact that, at the $\mathrm{pH}$ which gave the most rapid absorption, the plasma concentration reached a supposedly therapeutic level of $100 \mu \mathrm{g} / \mathrm{ml}$ already after 6-12 hrs. is considered to be of practical significance.

\section{Trond Bergsjø}

The Department of Pharmacology and Toxicology, Veterinary College of Norway, Oslo, Norway.

\section{REFERENCES}

Bratton, A. C. \& E. K. Marshall: New coupling component for sulfanilamide determination. J. biol. Chem. 1939, 128, 537-550.

King, E. H., G. A. D. Haslewood, G. E. Delory \& D. Beall: Micro-chemical methods of blood analysis. Lancet 1942, 242, 207-209.

Motais, R. \& F. Garcia-Romeu: Transport mechanisms in the teleostean gill and amphibian skin. Ann. Rev. Physiol. 1972, 34, $141-176$.

Rasmussen, F.: Studies on the Mammary Excretion and Absorption of Drugs. Copenhagen 1966.

Reite, O. B., G. M. O. Maloiy \& B. Aasehaug: $\mathrm{pH}$, salinity and temperature tolerance of Lake Magadi Tilapia. Nature (Lond.) 1974, 247, 5439, 315.

Shore, P. A., B. B. Brodie \& C. A. M. Hogben: The gastric secretion of drugs: A pH partition hypothesis. J. Pharmacol. exp. Ther. 1957, 119, 361-369.

Smith, J. N.: The comparative metabolism of xenobiotics. Advanc. comp. Physiol. Biochem. 1968, 3, 173-232.

(Received June 10, 1974).

Reprints may be requested from: Department of Pharmacology and Toxicology, Veterinary College of Norway, Postbox 8146, Oslo Dep., Oslo 1, Norway. 